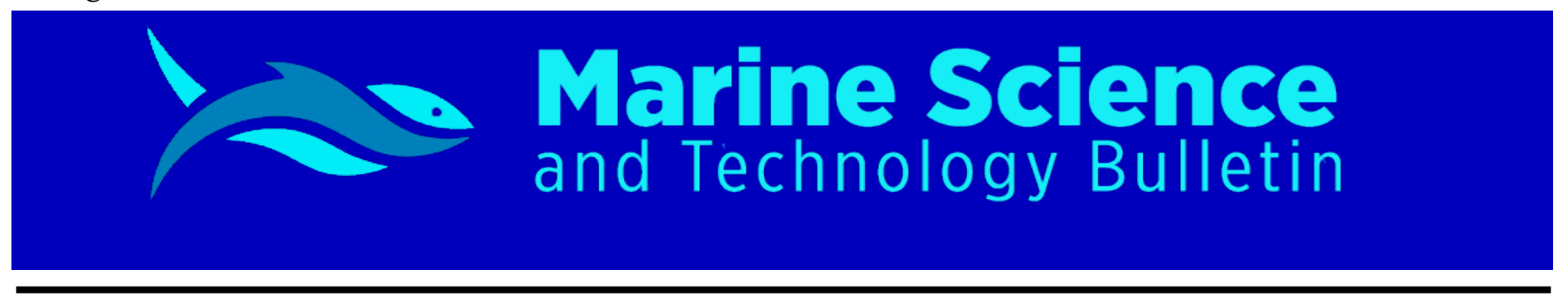

\title{
Length-weight relationship and condition factor of freshwater blenny Salaria fluviatilis (Asso, 1801) in Asi River (Hatay, Turkey)
}

\author{
Sibel Alagöz Ergüden ${ }^{1^{*}}$ (D) \\ ${ }^{1}$ Çukurova University, Imamoglu Vocational School, Fisheries Department, 01700, Imamoglu, Adana, Turkey
}

\begin{tabular}{|c|c|}
\hline ARTICLE INFO & A B S T R A C T \\
\hline $\begin{array}{l}\quad \text { Article History: } \\
\text { Received: } 18.08 .2020 \\
\text { Received in revised form: } 26.10 .2020 \\
\text { Accepted: } 29.10 .2020 \\
\text { Available online: } 14.11 .2020 \\
\quad \text { Keywords: } \\
\text { Blenniidae } \\
\text { Regression parameters } \\
\text { Inland waters } \\
\text { Asi River Basin } \\
\text { Turkey }\end{array}$ & $\begin{array}{l}\text { In this study, a total of } 109 \text { specimens ( } 57 \text { female and } 52 \text { male) of Salaria fluviatilis were } \\
\text { captured by tulle net and scooped net between October } 2017 \text { and March } 2018 \text { from the Asi River } \\
\text { system, Turkey. The length-weight relationship was } \mathrm{W}=0.0013 \mathrm{~L}^{3.054}\left(\mathrm{r}^{2}=0.967\right) \text { for both sexes } \\
\text { with isometric growth. The values of the exponent } b \text { of the length-weight relationships (LWRs) } \\
\text { were } 3.055 \text { for females and } 3.052 \text { for males. The b values for females, males, and both sexes were } \\
\text { not significantly different from } 3.0 \text { (P>0.05). Fulton condition factor (CF) was calculated } \\
1.3955 \pm 0.034 \text { for females, } 1.4495 \pm 0.042 \text { for males and } 1.4212 \pm 0.027 \text {, for both sexes. Estimations } \\
\text { of LWRs and CF for both sexes of } S \text {. fluviatilis, captured from Asi River, were provided for the } \\
\text { first time. }\end{array}$ \\
\hline
\end{tabular}

Please cite this paper as follows:

Alagöz Ergüden, S. (2021). Length-weight relationship and condition factor of freshwater blenny Salaria fluviatilis (Asso, 1801) in Asi River (Hatay, Turkey). Marine Science and Technology Bulletin, 10(1): 54-61.

\section{Introduction}

The freshwater blenny Salaria fluviatilis (Asso, 1801) is a member of the family Blenniidae and is well-known in the Mediterranean Region. S. fluviatilis is mainly a riverine species, naturally found in drainages around the northern Mediterranean and from Turkey, Israel to Portugal, and in Morocco and Algeria (Oliveira et al., 1992; Crivelli, 1996; Kottelat and Freyhof, 2007; Froese and Pauly, 2020). S. fluviatilis was reported from Seyhan Reservoir (Alagoz, 2005),

\footnotetext{
* Corresponding author

E-mail address: alagozs@cu.edu.tr (S.Alagöz Ergüden)
}

Ceyhan River (Alp and Kara, 2007) and drainage of the Black Sea (Bostanc1 et al., 2016), Aegean and some Mediterranean regions of Turkey (Geldiay and Balık, 1999; İlhan et al., 2013; Erguden, 2016; İnnal, 2019; Çiçek et al., 2020).

S. fluviatilis a common inhabitant of stony and gravel bottoms of rivers and brooks (Bath, 1986). It is generally preferred rubble and gravel substrate. Adults feed on small benthic organisms such as small snails and shrimps, and all kinds of insect larvae (Wilson, 2009). This species can reach up to $15.4 \mathrm{~cm}$ in total length (Laporte et al., 2012), and the maximum age is 5 (Kottelat and Freyhof, 2007). Females 
deposit a layer of eggs on the underside of the nest stone and the eggs are guarded against predators by the males (Cote et al., 1999). S. fluviatilis individuals start breeding at the end of the first year and a female can lay around 1200 eggs at one time (IUCN, 2020). Females lay an average of 200-300 eggs at a time, 2-30 times (Çoker et al., 2019). The number of eggs in a nest is around 500-8000 (Gasith and Goren, 2009).

S. fluviatilis is considered as Least Concern (LC) in the IUCN Global Red List for inland waters (IUCN, 2020), this species has affected and decreased from large parts of the Asi River drainage due to pollution, habitat destruction, and water abstraction. Thus, it is considered a locally endangered species listed by the IUCN Red List (Crivelli, 2006; Fricke et al., 2007).

Length-weight relationships (LWRs) are calculated for estimating the weight of a given length. LWRs are also useful for comparing life history and morphological aspects of populations inhabiting different habitats. Besides, LWRs are necessary for stock assessment and fisheries management (Pauly, 1983; Petrakis and Stergiou, 1995; Goncalves et al., 1997; Koutrakis and Tsikliras, 2003). Because the LWR values; in the length values for estimation of biomass, in the estimation of weight from a given length, and in stock estimation models transforming growth in length and growth in weight equations to each other for comparison of life cycle of a fishes from different areas are widely used by many researchers (Binohlan and Pauly, 1998; Froese, 2006).

Condition factor (CF) is used for comparing the fish's health or the fatness of the fish (Froese, 2006). The condition factor is an index reflecting interactions between biotic and abiotic factors in the physiological condition of the fishes. The condition of the fish is calculated from the estimation of the length-weight relationships. Thus, CF is also an essential parameter for the evaluation of fish stocks, and this parameter is widely used for studies of fisheries and fish biology.

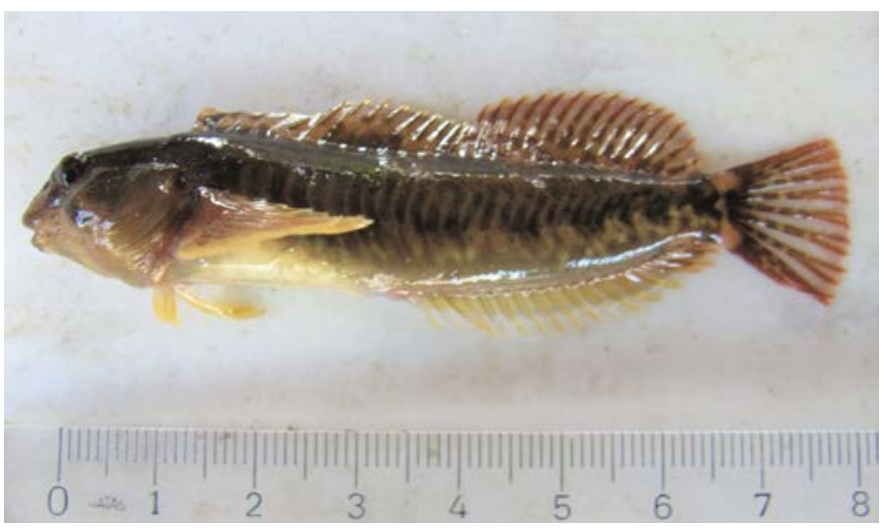

Figure 1. Salaria fluviatilis (Asso, 1801) captured in the Asi River

To date, a few studies regarding length-weight relationships of S. fluviatilis were in the eastern Mediterranean and the
Aegean Sea for the inland waters of Turkey (İlhan et al., 2013; Erguden, 2016; İnnal, 2019). However, LWRs and condition factors according to sexes for S. fluviatilis have not been reported from Turkey. Besides, there is no information on LWRs and CF for S. fluviatilis from the Asi River system (Southeastern Anatolia, Turkey). In the present paper, author reported on the estimations of LWRs and CF for both sexes of S. fluviatilis, captured from Asi River, were provided for the first time.

\section{Material and Methods}

A total of 109 (57 female and 52 male) specimens were captured from Asi (Orontes) River system using tulle net and scooped net at 0-2 m depths between October 2017 and March 2018 (Coordinates: $36^{\circ} 48^{\prime} \mathrm{N}, 36^{\circ} 10^{\prime} \mathrm{E}-36^{\circ} 53^{\prime} \mathrm{N}, 36^{\circ} 15^{\prime} \mathrm{E}$ ). Species identification follows Geldiay and Balık (1999) and confirmed based on FishBase (Froese and Pauly, 2020) (Figure 1). Total length (TL) was measured to the nearest $0.1 \mathrm{~cm}$ by means of a vernier caliper and total weight was recorded to the nearest $0.01 \mathrm{~g}$ on a precision balance. The sex of each specimen was determined by examining the gonads macroscopically. Chi-square $\left(\chi^{2}\right)$ analysis was used to test the significant differences between the sex ratio.

The relationship between the length and weight of the fish samples were estimated using the equation

$$
W=a L^{b}(\text { Ricker, 1975) }
$$

where $W$ is the weight of the fish, TL is the total length, and $a$ and $b$ are constants. The relationship between total length, TL, and weight was calculated for females, males, and all individuals. The significance of the regression was assessed by ANOVA. The student's t-test was applied to determine the significance of differences ( $95 \%$ level) between the isometric growth $(b=3)$ and the estimated $b$ value of the equation.

Fulton's coefficient of condition factor (CF) was calculated by the formula given below.

$$
C F=\frac{W}{L^{3}} \times 100
$$

where; $L$ is length $(\mathrm{cm})$ and $W$ is weight (g) (Bagenal, 1978; Sparre and Venema, 1992).

The relationships among the variables were identified using the regression analysis. The observed differences were evaluated statistically using SPSSv. 22.0 package program and Student's t-test (Sokal and Rohlf, 1969).

\section{Results}

Of the 109 specimens, 57 were (52.30\%) females, 52 were males $(47.70 \%)$. The sex ratio for female and male individuals 
(F:M) was 1.00:0.91. The $\chi^{2}$ test showed $\left(\chi^{2}=3.819, \mathrm{P}>0.05\right)$ that there was no significant difference in sex ratio from the expected 1:1. Total length in females ranged from $1.7-7.1 \mathrm{~cm}$ with a mean of $3.23 \pm 1.32 \mathrm{~cm}$. Total length in males ranged from $2.0-6.8 \mathrm{~cm}$ with a mean of $3.29 \pm 1.33 \mathrm{~cm}$. The mean total weights of females and males values were $0.78 \pm 1.10 \mathrm{~g}$ and $0.81 \pm 1.09 \mathrm{~g}$, respectively (Table 1 ). The t-test showed that there was significant difference between sexes in overall total length and total weight $(\mathrm{t}=1.477, \mathrm{P}<0.05)$. Females were more abundant length class (in $3.5-2.5 \mathrm{~cm}$ ) than males (in $3.0-2.0 \mathrm{~cm}$ ) in the length class. The dominant length class in the total samples was 2-2.5 $\mathrm{cm}$ (Figure 2).

The $b$ values of length-weight relationship, which were not significantly different between sexes (ANOVA, P>0.05), indicated isometric growth for females $(b=3.055)$, males $(b=3.052)$ and both sexes $(b=3.054)$. The estimated parameters of the length-weight relationship parameters are given in Table 2. The LWRs were described as $W=0.0012 \mathrm{xL}^{3.055}\left(\mathrm{r}^{2}=0.969\right)$ for females, $\mathrm{W}=0.0012 \mathrm{xL}^{3.052}\left(\mathrm{r}^{2}=0.965\right)$ for males, and $\mathrm{W}$ $=0.0013 \times L^{3.054}\left(r^{2}=0.967\right)$ for both sexes. Estimation of lengthweight relationship for female, male, and both sexes are given in Figure 3.

The length-weight relationships were isometric growth in $S$. fluviatilis samples for females, males, and both sexes. The $b$ values for females, males, and both sexes were not significantly different from $3.0(b=3, \mathrm{P}>0.05)$, (Table 2$)$. In addition to the present study, a comparison of published length-weight relationship parameters in different regions for $S$. fluviatilis is given in Table 3.

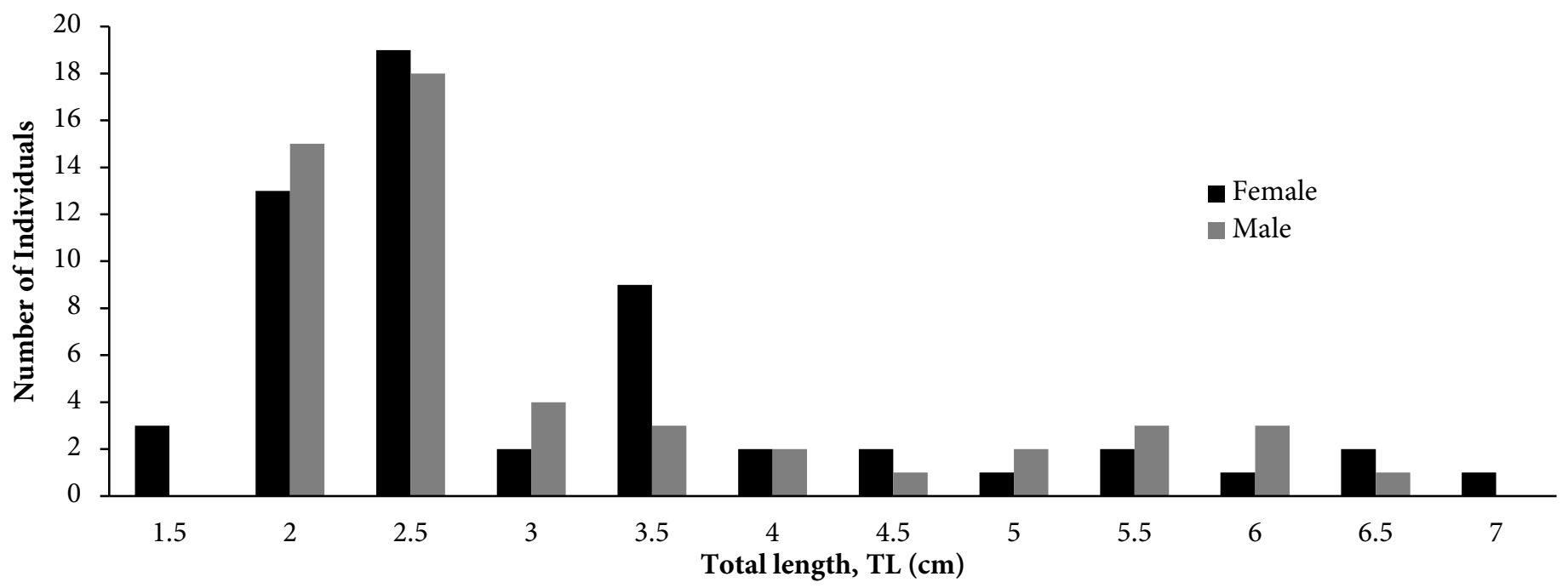

Figure 2. Length frequency distributions of $S$. fluviatilis collected in Asi River

Table 1. Mean and standard deviation, minimum, maximum, for total length (TL) and weight (W) characteristics according to sexes of S. fluviatilis occurring in the Asi River

\begin{tabular}{lccccc}
\hline Sex & $\mathbf{N}$ & $\mathbf{L}_{\min }-\mathbf{L}_{\max }(\mathbf{c m})$ & Mean \pm SD & $\mathbf{W}_{\min }-\mathbf{W}_{\max }(\mathbf{c m})$ & $\mathbf{M e a n}_{\mathbf{S}} \mathbf{S D}$ \\
\hline Female & 57 & $1.70-7.10$ & $3.23 \pm 1.32$ & $0.07-4.85$ & $0.78 \pm 1.10$ \\
Male & 52 & $2.00-6.80$ & $3.29 \pm 1.33$ & $0.10-4.37$ & $0.81 \pm 1.09$ \\
Both & 109 & $1.70-7.10$ & $3.26 \pm 1.32$ & $0.07-4.85$ & $0.78 \pm 1.10$
\end{tabular}

Note: N: Sample Size; S.D: Standard Deviation Min: Minimum; Max: Maximum

Table 2. Length-weight relationship parameters for S. fluviatilis in Asi River (Southeastern Anatolia)

\begin{tabular}{llllllllll}
\hline Sex & $\mathbf{N}$ & $\mathbf{a}$ & $\mathbf{b}$ & $\mathbf{\pm S . E}(\mathbf{b})$ & $\mathbf{9 5 \%}$ C.I. of b & $\mathbf{r}^{2}$ & t-test & $\mathbf{P}$ & $\mathbf{G r o w t h}$ \\
\hline Female & 57 & 0.00120 & 3.055 & 0.073 & $2.908-3.201$ & 0.969 & 0.587 & $>0.05$ & Isometry \\
Male & 52 & 0.00120 & 3.052 & 0.082 & $2.888-3.216$ & 0.965 & 0.974 & $>0.05$ & Isometry \\
Both & 109 & 0.00130 & 3.054 & 0.054 & $2.947-3.154$ & 0.967 & 1.097 & $>0.05$ & Isometry
\end{tabular}

Note: N: Sample Size, a: Intercept of the relationship; b: Slope of the relationship; S.E.(b): Standard Error of b; $\mathrm{r}^{2}$ : Coefficient of determination, C.I.: Confidence Interval 

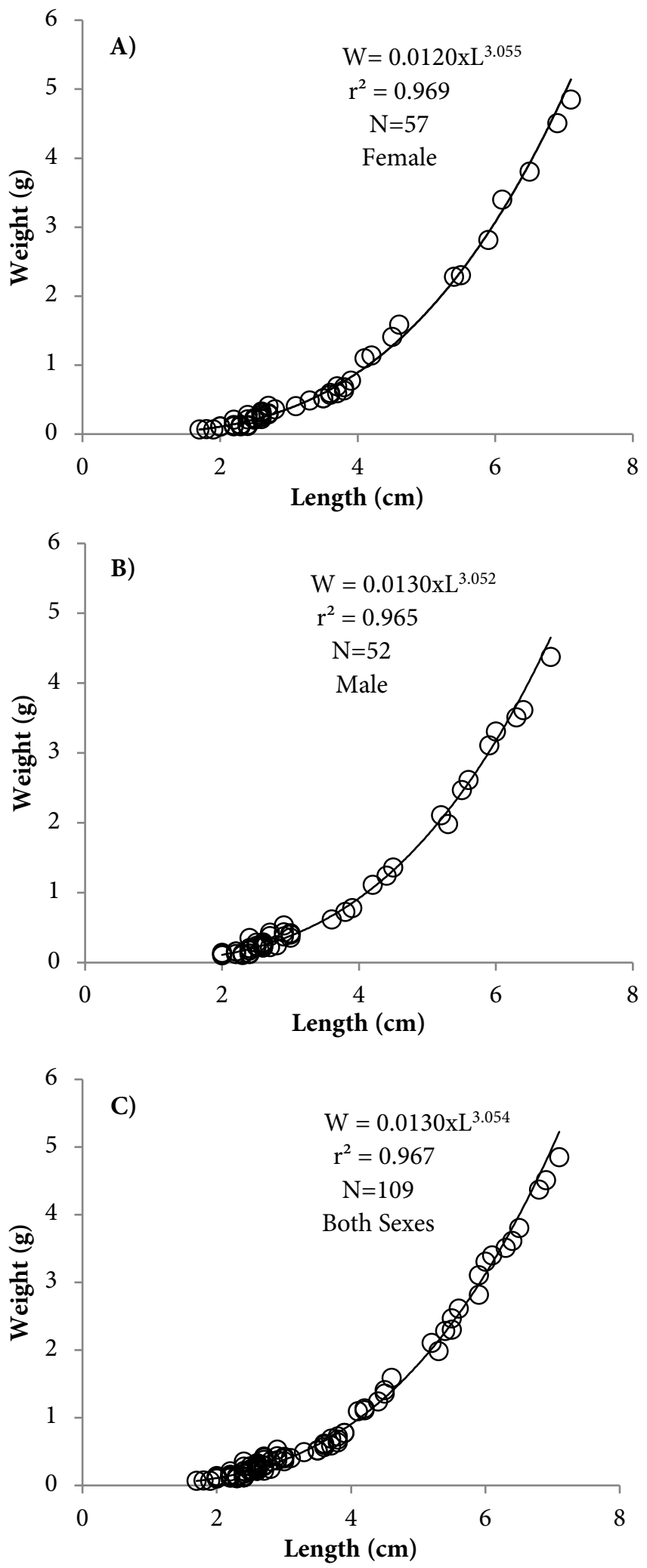

Figure 3. Length-weight relationship of S. fluviatilis. (A), female (B), male and (C), both sexes in Asi River (Southeastern Anatolia, Turkey)

The present study, Fulton condition factor (CF) value was estimated as $1.3955 \pm 0.034$, for females, as $1.4495 \pm 0.042$ for males and as $1.4212 \pm 0.027$ for both sexes. Condition factor values showed no significant variations $(\mathrm{P}>0.05)$ of $S$. fluviatilis for between sexes.

\section{Discussion}

Investigations carried out on 109 specimens of S. fluviatilis, captured in the Asi River, revealed a sex ratio (males: females) of 1.00:0.91. Besides, it was also observed that females were more dominant in the population (Figure 2). In a study conducted in Ceyhan River by Alp \& Kara (2007) reported the female/male ratio (F:M) as 0.69:1.00. Neat et al. (2003) determined as 0.73 in Lake Kournas, 0.58 in the Fango River, and 0.61 in Lake Garda (Italy). In the present study, the sex ratio of $S$. fluviatilis in the Asi River was slightly different from those in these previous reports, but similarly, females are dominant than males. According to Cote et al. (1999) The differences in the sex ratio of $S$. fluviatilis may be due to the egg guarding behavior of the males.

Total lengths of examined specimens of $S$. fluviatilis ranged between 1.7 and $7.1 \mathrm{~cm}$. This finding is similar to the studies from different regions, e.g., 2.0-7.0 cm Kleanthidis et al. (1999) from Greece (Lake Trichonis); 2.0-7.5 cm (Erguden, 2016) from the Southeastern Anatolia, Turkey; 2.1-7.5 cm from western Mediterranean brackish water of Turkey (İnnal, 2019). Other results having considerably lower length range were also reported from different locations such as $2.4-6.5 \mathrm{~cm}$ from Rhios estuary, NW Aegean, Greece (Koutrakis and Tsikliras, 2003), 2.3-4.8 cm from Lake Iznik, Turkey (Tarkan et al., 2006). However, as a different result, İlhan et al. (2013) from Turkey Inland waters (7 drainage basin) declared maximum length $(\mathrm{TL}=12.9 \mathrm{~cm})$ for $S$. fluviatilis. The length differences in values might be explained with the habitat differences, environmental factors and catch period. Moreover, the size of fishes may fluctuate due to gender, season, feeding rate, gonadal development, water flow, and their behavior (Tarkan et al., 2006).

The values of the exponent $b$ provide information on fish growth. When $b=3$, the increase in weight is isometric. When the value of $b$ is higher than 3 , the weight increase is allometric (positive if $b>3$, negative if $b<3$ ). In the present study, the $b$ values ranged from 3.055 for female to 3.052 for male individuals of $S$. fluviatilis.

Based on previously reported studies, positive allometry and isometry were observed in S. fluviatilis from the west and the east Mediterranean inland waters of Turkey (Table 3). The presented paper, the $b$ values were generally in similar results for S. fluviatilis reported from other geographical areas (Kleanthidis et al., 1999; Tarkan et al., 2006; İlhan et al., 2013; Erguden, 2016). The observed small differences could be due to the fishing equipment, season, fishing pressure, sampling 
Table 3. Length-weight relationships of S. fluviatilis from different regions

\begin{tabular}{|c|c|c|c|c|c|c|c|c|}
\hline Author(s) & Locality & Sex & $\mathbf{N}$ & Lt & Length $(\mathrm{cm})$ & $\mathbf{a}$ & $\mathbf{b}$ & $\mathbf{r}^{2}$ \\
\hline \multirow{2}{*}{ Kleanthidis et al. (1999) } & \multirow{2}{*}{ Lake Trichonis, Greece } & Female & 441 & $\mathrm{TL}$ & $2.0-7.0$ & 0.01020 & 3.080 & 0.941 \\
\hline & & Male & 409 & $\mathrm{TL}$ & $2.0-7.0$ & 0.00680 & 3.330 & 0.980 \\
\hline Koutrakis and Tsikliras (2003) & $\begin{array}{l}\text { Rhios estuary, } \\
\text { NW Aegean, Greece }\end{array}$ & Mixed & 5 & $\mathrm{TL}$ & $2.4-6.5$ & 0.01220 & 2.986 & 0.986 \\
\hline Tarkan et al. (2006) & Lake İznik, Marmara & Mixed & 92 & $\mathrm{TL}$ & $2.3-4.8$ & 0.00960 & 3.060 & 0.933 \\
\hline Erguden (2016) & Seyhan Reservoir, Turkey & Mixed & 97 & $\mathrm{TL}$ & $2.0-7.5$ & 0.01170 & 3.084 & 0.962 \\
\hline This study & Asi River, Turkey & Mixed & 109 & $\mathrm{TL}$ & $1.7-7.1$ & 0.00130 & 3.054 & 0.967 \\
\hline
\end{tabular}

Note: Lt: Length type

procedure, sample size, length range, reproduction season and environmental or habitat factors (Petrakis and Stergiou, 1995). However, the previous two reports of positive allometric growth of $S$. fluviatilis has also been reported by Kleanthidis et al. (1999) (male samples; b=3.330 for Lake Trichonis, Greece) and by İnnal (2019) $(b=3.308$ for W. Mediterranean brackish water). On the contrary, Koutrakis and Tsikliras (2003) from Rhios estuary of Greece has reported negative allometric growth $(b=2.986)$. These differences could be the result of environmental variations or habitat factors (Hossain et al., 2015), including seasonal effect, degree of stomach fullness, gonad maturity, food richness (Gonzalez et al., 2004; RuizCampos et al., 2006), sex, health, reproductive period, and seasonal variation (Bagenal and Tesch, 1978; Alp et al., 2005).

According to Bagenal and Tesch (1978) and Goncalves et al. (1997), the parameters of $b$ generally do not vary significantly throughout the year, unlike parameter $a$, which may vary seasonally, daily, and between habitats. Besides, several factors are known to influence the LWRs in fish, including habitat, general fish condition, gonad maturity, season, and preservation of fish (Tesch, 1971; Bagenal and Tesch, 1978; Wootton, 1990), these factors were not accounted in the present study.

The coefficient of determination $\left(\mathrm{r}^{2}\right)$ was found to be $>0.96$, a highly significant value of the result. The regression analysis has demonstrated that fish length had a highly significant correlation with weight $(\mathrm{P}<0.001)$.

Le Cren (1951) and Ricker (1975), reported the condition factor of fish populations may show variations with gonad development, feeding activity and seasonal changes in growth.
In this study, CF values were also calculated, where the lowest and highest estimations were found to be 1.3955 and 1.4495, respectively, with a mean value of $1.4212 \pm 0.027$ for both sexes. Le Cren (1951) declared that CF values greater than 1 indicated the good condition of the fish whereas a value $<1$ is indicative of the reverse nature. The present results revealed that both males and females indicate that both of the sexes are in good condition for S. fluviatilis.

\section{Conclusion}

The present study provides the first reference on LWRs and $\mathrm{CF}$, of S. fluviatilis. Besides, the CF value of S. fluviatilis calculated for both sexes showed that it was in a very good condition in terms of its optimum growth in the Asi River. This study is also useful for fishery biologist, sustainable fishery management, and conservation.

S. fluviatilis is considered a locally endangered species listed by the IUCN Red List (Crivelli, 2006; IUCN, 2020). Besides, this species is locally threatened inland waters of Turkey due to dams built on rivers, habitat destruction, pollution, and water abstraction in the next years (Fricke et al., 2007). Today, S. fluviatilis has affected and decreased from large parts of the Asi drainage due to water pollution habitat destruction and introduction of exotic species. Therefore, a conservation action should be taken as a high priority for this species.

\section{Acknowledgements}

I would like to thank Murat Devecili for his assistance. 


\section{Compliance with Ethical Standards}

\section{Conflict of Interest}

The author declares that there is no conflict of interest.

\section{Ethical Approval}

This study was conducted in accordance with ethics committee procedures of animal experiments. All procedures were performed in accordance with the Law on Veterinary and Medical Activities and National Animal Welfare Act. Therefore, ethics approval was not required.

\section{References}

Alagoz, S. (2005). Determination of ichthyofauna in the Seyhan Dam Lake (Adana). MSc Thesis. Cukurova University, Adana, Turkey.

Alp, A., Kara, C. H., Büyükçapar, M. \& Bülbül, O. (2005). Age, growth and condition of Capoeta capoeta angorae, Hanko 1924 from the upper water systems of the River Ceyhan, Turkey. Turkish Journal of Veterinary and Animal Sciences, 29: 665-676.

Alp, A. \& Kara, C. H. (2007). Distribution pattern and morphological differences between the sexes of river blenny, Salaria fluviatilis (Asso, 1801), in the Ceyhan River Basin, Turkey. Turkish Journal of Zoology, 31: 113120.

Bagenal, T. B. (1978). Methods for Assessment of Fish Production in Fresh Waters. (3rd ed.), Handbook No: 3, Blackwell Scientific Publication, Oxford, 365p.

Bagenal, T. B. \& Tesch, F. W. (1978). Age and growth (pp. 101136). In: Bagenal, T. (Ed.), Methods for assessment of fish production in fresh waters. (3rd ed.), IBP Handbook No. 3, UK: Blackwell Scientific Publications, Oxford.

Bath, H. (1986). Blenniidae (pp. 355-357). In: Daget, J., Gosse, J. P., Thys van den Audenaerde, D. F. E. (Eds.), Checklist of the freshwater fishes of Africa (CLOFFA). Vol. 2. ISNB, Brussels, MRAC, Tervuren; and ORSTOM, Paris.

Binohlan, C. \& Pauly, D. (1998). The length-weight table (pp. 121-123). In: Froese, R., Pauly, D. (Eds.), FishBase 1998: Concepts, design and data sources. ICLARM, Manila.

Bostanc1, D., Darçın, M. \& Helli, S. (2016). A study on the investigation of fish fauna of Yalıköy Stream (Ordu). Ordu University Journal of Science and Technology, 6(2): 146-157.
Cote, I. M., Vinyoles, D., Reynolds, J. D., Doadrio, I. \& Perdices, A. (1999). Potential impacts of gravel extraction on Spanish populations of river blennies Salaria fluviatilis (Pisces, Blenniidae). Biological Conservation, 87: 359367.

Crivelli, A. J. (1996). The freshwater fish endemic to the Mediterranean region. An action plan for their conservation. Tour du Valat Publication, 171p.

Crivelli, A. J. (2006). Salaria fluviatilis. The IUCN Red List of Threatened Species 2006: e.T60764A12407160. Retrieved on 11 September 2020 from https://dx.doi.org/10.2305/IUCN.UK.2006.RLTS.T6076 4A12407160.en.

Çiçek, E., Sungur, S. \& Fricke, R. (2020). Freshwater lampreys and fishes of Turkey; a revised and updated annotated checklist 2020. Zootaxa, 4809(2): 241-270. https://doi.org/10.11646/zootaxa.4809.2

Çoker, T. (2019). Morphological characteristics of eggs and larvae of Salaria fluviatilis (Asso, 1801) (Family: Blenniidae) Collected from Akyaka Azmak Creek. LIMNOFISH-Journal of Limnology and Freshwater Fisheries Research, 5(3): 220-225. http://doi.org/10.17216/LimnoFish.484462

Erguden, S. A. (2016). Length-weight relationships for six freshwater fish species from the Seyhan Reservoir (south-eastern Anatolia, Turkey). Journal of Applied Ichthyology, 32:

141-143. https://doi.org/10.1111/jai.12905

Fricke, R., Bilecenoglu, M. \& Sarı, H. M. (2007). Annotated checklist of fish and lamprey species (Gnathostomata and Petromyzontomorphi) of Turkey, including a Red List of threatened and declining species. Stuttgarter Beitragezur Naturende Serie A, 706: 1-172.

Froese, R. (2006). Cube law, condition factor and weight length relationships: history, meta-analysis and recommendations. Journal of Applied Ichthyology, 22(4): 241-2530. https://doi.org/10.1111/j.14390426.2006.00805.x

Froese, R. \& Pauly, D. (2020). Fishbase.Worldwide Web Electronic Publication. Retrieved on August 16, 2020 from https://www.fishbase.se/summary/54714

Geldiay, R. \& Balık, S. (1999). Freshwater Fishes in Turkey, (in Turkish). Ege University Fisheries Faculty Press, No: 46, (3. Ed.), Bornova, İzmir, Turkey. 532p. 
Goncalves, J. M. S., Bentes, L., Lino, P. G., Ribeiro, J., Canario, A. V. M. \& Erzini, K. (1997). Weight-length relationships for selective fish species of the small scale demersal fisheries off the South and Southwest coast of Portugal. Fisheries Research, 30: 253-256. https://doi.org/10.1016/S0165-7836(96)00569-3

Gonzalez, A, De La Cruz Aguero, A. F. G. \& De La Cruz Aguero,

J. (2004). Length weight relationships of fish species caught in a mangrove swamp in the Gulf of California (Mexico). Journal of Applied Ichthyology, 20: 154-155.

Gasith, A. \& Goren, M. (2009). Habitat availability, reproduction and population dynamics of the freshwater blenny Salaria fluviatilis (Asso, 1801) in Lake Kinneret, Israel. Electronic Journal of Ichthyology, 2: 3446.

Hossain, M. Y., Sayed, S. R. M., Rahman, M. M., Ali, M. M., Hossen, M. A., Elgorban, A. M. \& Ohtomi, J. (2015). Length-weight relationships of nine fish species from the Tetulia River, southern Bangladesh. Journal of Applied Ichthyology, 31: 967-969. https://doi.org/10.1111/j.1439-0426.2011.01900.x

IUCN, (2020). The IUCN Red List of Threatened Species. Version 2020-2. Retrieved on September 14, 2020 from https://www.iucnredlist.org

İlhan, A., Ustaoğlu, M. R. \& Berberoğlu, S. (2013). The lengthweight relationship of freshwater blenny, Salaria fluviatilis (Asso, 1801) in 7 drainage basin of Turkey. Ege Journal of Fisheries Aquatic Sciences, 30(1): 41-43.

İnnal, D. (2019). Diversity and length-weight relationships of Blenniid species (Actinopterygii, Blenniidae) from Mediterranean brackish waters in Turkey. Aquatic Sciences and Engineering, 34(3): 96-102. https://doi.org/10.26650/ASE2019573052

Kleanthidis, P. K., Sinis A. I. \& Stergiou, K. I. (1999). Lengthweight relationships of freshwater fishes in Greece. Naga, ICLARM Quarterly, 22(4): 37-41.

Kottelat, M. \& Freyhof, J. (2007). Handbook of European freshwater fishes. Publications Kottelat, Cornol and Freyhof, Berlin. 646p.

Koutrakis, E. T. \& Tsikliras, A. C. (2003). Length-weight relationships of fishes from three northern Aegean estuarine systems (Greece). Journal of Applied Ichthyology, 19: 258-260.
Laporte, M., Mattei, J., Perret, P., Roché, B., Vinyoles, D., Goren, M., Bacha, M., Mourad, Z., Pou, I., Roviram, Q., Berrebi, P. \& Magnan, P. (2012). New maximum lengths for the freshwater blenny (Salaria fluviatilis Asso, 1801) and length comparison between continental and island rivers. Cybium, 37(4): 309-313.

Le Cren, E. D. (1951). The length-weight relationship and seasonal cycle in gonad weight and condition in the perch (Perca fluviatilis). Journal of Animal Ecology, 20: 201-219.

Neat, F. C., Lengkeek, W., Westerbeek, E. P., Laarhoven, B. \& Videler, J. J. (2003). Behavioural and morphological differences between lake and river populations of Salaria fluviatilis. Journal of Fish Biology, 63: 374-387.

Oliveira, R. F., Almada, V. C., Almeida, A. J., Santos, R. S. \& Gonçalves, E. J. (1992). A checklist of the blennioid fishes (Teleostei, Blennioidei) occurring in Portuguese waters. Arquipélago. Ciencias da Natureza, 10: 23-37.

Pauly, D. (1983). Some simple methods for the assessment of tropical fish stocks. FAO Fisheries Technical Report, No: 234, FAO, Rome. 52p.

Petrakis, G. \& Stergiou, K. I. (1995). Weight length relationships for 33 fish species in Greek water. Fisheries Research, 21: 465-469. https://doi.org/10.1016/01657836(94)00294-7

Ricker, W. E. (1975). Computation and interpretation of biological statistics of fish populations. Bulletin Fisheries Research Board of Canada, 191: 1-382.

Ruiz-Campos, G., González Acosta, A. F. \& De La Cruz Aguero, J. (2006). Length-weight and length-length relationships for some continental fishes of northwestern Baja California, Mexico. Journal of Applied Ichthyology, 22: 314-335. https://doi.org/10.1111/j.1439-0426.2006.00780.x

Sokal, R. R. \& Rohlf, F. J. (1969). Introduction to Biostatistics. (2nd Ed.), New York, USA: W.H. Freeman and Company. 363p.

Sparre, P. \& Venema, S. C. (1992). Introduction to Tropical Fish Stock Assessment, Part I. FAO Fisheries Technical Paper 306/1, Rome. 376p.

Tarkan, A. S., Gaygusuz, O. Acipinar, H. Gürsoy C. \& Ozulug, M. (2006). Length-weight relationship of fishes from the Marmara region (NW-Turkey). Journal of Applied Ichthyology, 22: 271-273. https://doi.org/10.1111/j.1439$\underline{0426.2006 .00711 . x}$ 
Tesch, F. W. (1971). Age and growth (pp. 98-103). In: Ricker, W. E. (Ed.), Methods for assessment of fish production in fresh waters. (1st ed.). Oxford, UK: Blackwell Scientific Publications. 348p.

Wilson, S. K. (2009). Diversity in the diet and feeding habits of Blennies (pp. 139-162). In: Patzner, R. A., Gonçalves, E. J., Hastings, P. A. and Kapoor, B. G. (Eds.), The biology of blennies. Enfield, NH: Science Publishers. 482p.
Wootton, R. J. (1990). Ecology of Teleost Fishes. Fish and Fisheries Series 1, Chapman \& Hall, London. 404p. 